\title{
Western Wheatgrass Responses to Simulated Grazing
}

\author{
D.O. STROUD, R.H. HART, M.J. SAMUEL, AND J.D. RODGERS
}

\begin{abstract}
To evaluate responses of range grasses to herbage removal, removal patterns should simulate those under grazing. We compared responses of western wheatgrass (Agropyron smithii $\mathrm{Rydb}$.) in mixed-grass range to no clipping, conventional clipping, and clipping which simulated continuous grazing. Two years of simulated grazing did not affect herbage production or tiller numbers, but both declined under conventional clipping. Belowground phytomass decreased as herbage removal increased. Total nonstructural carbohydrate concentration in rhizomes decreased when utilization exceeded about $40 \%$, but that of roots and crowns decreased only when utilization exceeded $60-70 \%$.
\end{abstract}

Most clipping studies of range grasses make little effort to simulate herbage removal patterns which occur under grazing. Clipping studies usually include clipping at uniform heights, not random heights as occurs under grazing (Jameson 1963), and more severe defoliation than occurs under grazing (Heady 1961). Harris (1976) indicated that frequency, intensity, and timing of defoliation all influence plant responses. Iack of knowledge of these parameters has inhibited design of realistic clipping experiments.

Hart and Balla (1982) photographed western wheatgrass ( Agropyron smithii $\mathrm{Rydb}$.) tillers at intervals during the grazing season and determined frequency, intensity, and timing of herbage removal. We used this information to design a clipping experiment which simulated grazing more closely than ever before, and compared response of western wheatgrass under simulated grazing to that under conventional clipping and no clipping. Our objective was to provide better guides to grazing management than could be provided from responses to conventional clipping.

\section{Methods and Materials}

This research was initiated in 1980 on mixed-grass range at the USDA High Plains Grasslands Research Station, near Cheyenne, Wyo. The major grass species are blue grama (Bouteloua gracilis [H.B.K. [Lag. ex Griffiths.), western wheatgrass, and needleand-

Authors are, respectively, former graduate assistant, Division of Range Management, University of Wyoming, Laramie; agronomist and botanist, U.S. Department of Agriculture. Agricultural Research Service, High Plains Grasslands Research Station, 8408 Hildreth Road, Cheyenne, WY 82009; and associate professor, Division of Range Management, UW, Laramie. Stroud's current address is Route 1, Yoder, WY 82244 .

Manuscript accepted June 25, 1984. thread (Stipa comata Trin. \& Rupr.). Soils underlying the study plots were a fine-loamy Aridic Argiustoll of the Altvan Series. Stevenson et al. (1984) have given a more complete description of the range sites and vegetation of the research station.

Twenty-four plots $(25 \times 40 \mathrm{~cm})$ were established on an area of native range ungrazed since 1978 and containing $450-600$ tillers $/ \mathrm{m}^{2}$ of western wheatgrass. Each plot was bordered by aluminum lawn edging placed into the ground approximately $20 \mathrm{~cm}$ to eliminate rhizome spread between plots and between the plots and adjacent native range.

Four replications of 6 treatments, in a randomized complete block design, were applied to the 24 plots. The 6 treatments included an unclipped control, clipping western wheatgrass to 2.5 $\mathrm{cm} 4$ times during the summer, and 4 clipping treatments simulating 4 levels of continuous grazing of western wheatgrass.

Frequency under simulated continuous grazing was defined as the percentage of tillers clipped $0,1,2,3$, or 4 times, while intensity was the percentage of clipping events at which $1 / 3,2 / 3$, or all the aboveground herbage was removed from a tiller. Two frequencies (Table 1) times 2 intensities (Table 2) gave us 4 simulated grazing treatments.

Table 1. Explanation of clipping frequency treatments "F1" and "F2".

\begin{tabular}{lccc}
\hline \hline \multirow{2}{*}{$\begin{array}{l}\text { Times } \\
\text { clipped }\end{array}$} & \multicolumn{2}{c}{ Treatment "F1" } & Treatment "F2" \\
\cline { 2 - 3 } & 1980 & 1981 & $1980-81$ \\
\hline & \multicolumn{3}{c}{$-0 \%$ of tillers clipped - - } \\
0 & 10 & 10 & 0 \\
1 & 15 & 35 & 5 \\
2 & 35 & 30 & 35 \\
3 & 30 & 20 & 40 \\
4 & 10 & 5 & 20 \\
\hline
\end{tabular}

Under simulated grazing, all western wheatgrass tillers in each plot were individually labeled with small, numbered bird leg bands, and a clipping schedule prepared for each tiller. Frequency of clipping, the intensity of herbage removal at each clipping, and the dates of clipping were randomly assigned to each tiller, with the limitation that all the herbage could be removed only at the last 


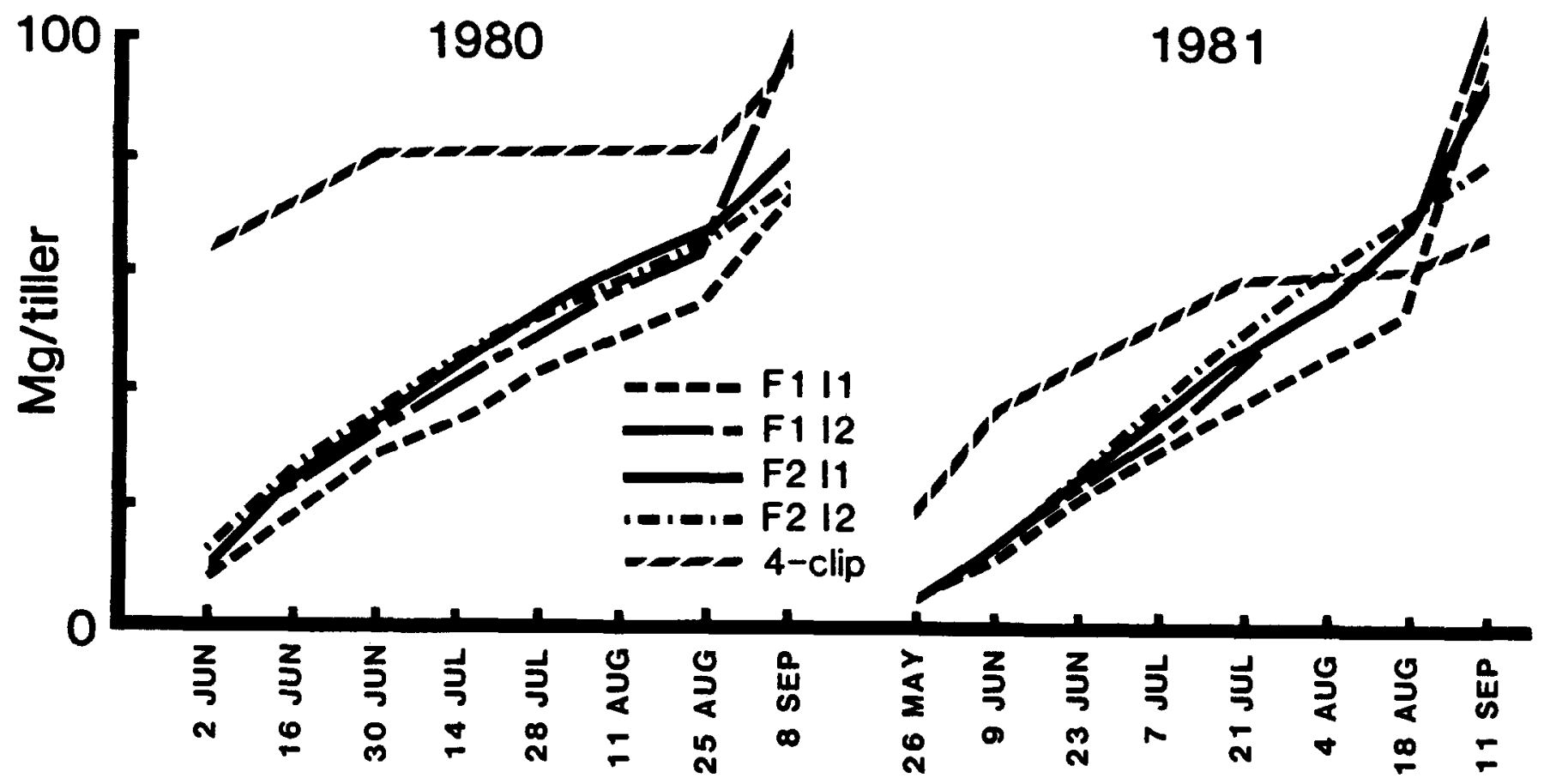

Fig. 1. Cumulative herbage production of western wheatgrass tillers under 5 clipping treatments (see Tables 1 and 2 for explanation of "F" and " $I$ " treatments; "4-clip" was clipped 4 times during the growing season to a height of $2.5 \mathrm{~cm}$ ).

clipping of a tiller. It must be emphasized that a separate clipping schedule was developed for each tiller, to simulate the random and nonuniform herbage removal patterns observed under actual grazing. A partial sample clipping schedule for one plot is shown in Table 3, and clipping dates are shown in Figure 1.

Table 2. Explanation of clipping intensity treatments " 11 " and " 12 ".

\begin{tabular}{|c|c|c|c|}
\hline \multirow{2}{*}{$\begin{array}{l}\text { Amounts } \\
\text { removed }\end{array}$} & \multicolumn{2}{|c|}{ Treatment "Il" } & \multirow{2}{*}{$\begin{array}{c}\text { Treatment "I2" } \\
1980-81\end{array}$} \\
\hline & 1980 & 1981 & \\
\hline & \multicolumn{3}{|c|}{$--\%$ of grazing events --} \\
\hline $\begin{array}{l}1 / 3 \\
2 / 3 \\
\text { All }\end{array}$ & $\begin{array}{l}40 \\
50 \\
10\end{array}$ & $\begin{array}{l}60 \\
30 \\
10\end{array}$ & $\begin{array}{l}20 \\
60 \\
20\end{array}$ \\
\hline
\end{tabular}

Table 3. Sample clipping schedule for western wheatgrass tillers on a single plot (treatment F1I1, 1980; for explanation of treatments, see Tables 1 and 2).

\begin{tabular}{lccccccccc}
\hline \hline & \multicolumn{10}{c}{ Amount removed: } \\
\cline { 2 - 8 } $\begin{array}{l}\text { Tiller } \\
\text { number }\end{array}$ & 2 & 16 & 30 & 14 & 28 & 11 & 25 & 8 \\
\hline 1 & Jun & Jun & Jun & Jul & Jul & Aug & Aug & Sep \\
\hline 2 & - & - & $2 / 3$ & - & - & $1 / 3$ & - & All \\
3 & - & - & $1 / 3$ & - & - & - & $1 / 3$ & All \\
4 & $1 / 3$ & - & - & - & $2 / 3$ & - & $1 / 3$ & All \\
$\bullet$ & - & - & - & $2 / 3$ & - & All & - & - \\
55 & - & $\bullet$ & $\bullet$ & $\bullet$ & r & $\bullet$ & $\bullet$ & $\bullet$ \\
\hline
\end{tabular}

All western wheatgrass tillers were clipped under the 4-clip treatment, at $2.5 \mathrm{~cm}$ from ground level on clip dates $1,3,5$, and 7 . This represents a severe uniform clipping comparable to that applied in many previous clipping trials.

Western wheatgrass herbage removed from each plot at each of the first 7 clipping dates each year was dried and weighed. At the last clipping, when the season's growth was completed, all remaining herbage was clipped by species, dried, and weighed. Total production was the sum of all 8 clippings; utilization was the sum of the first 7 clippings, divided by total production.

Tillers were counted before the first clipping and at the last clipping in 1980 and 1981. Production per tiller was calculated from spring tiller counts. Very few new tillers were produced after the spring count, but some tillers died. At each clipping date in 1981, 18 to 29 tillers of western wheatgrass were harvested outside the plots and dissected to determine phenology and apical meristem height.

In the fall of 1981,2 replications of each treatment were excavated. Entire plots were cut loose and lifted, and these sod blocks were trimmed to a $15-\mathrm{cm}$ depth. Sampling at similar sites showed $73 \%$ of belowground phytomass, including all the crowns and rhizomes, were found in the top $15 \mathrm{~cm}$ (T. Tarassoum, unpublished data). Soil was washed from the belowground phytomass and the phytomass was separated by species, washed a final time, ovendried and weighed. Western wheatgrass was further separated into crowns, rhizomes, and roots. These were then ground in a Wiley mill (1-mm mesh screen) and analyzed for total nonstructural carbohydrates (TNC) by a modified Weinmann Method and a method of Shaffer-Somogyi for determination of reducing power (Smith 1981).

In the fall of 1982 after a season of rest, the remaining 12 plots were clipped by species to ground level, oven-dried, and weighed to assess residual effects of the treatments on herbage production of western wheatgrass and other species. Tillers of western wheatgrass were counted at this time.

Aboveground and belowground production data were analyzed utilizing analysis of covariance procedures, with initial tiller numbers as the independent and production as the dependent variable, to adjust for initial variation in tillers per plot. A split plot design was utilized to analyze total nonstructural carbohydrates, and least square means were used to compare means from the above analyses. Orthogonal contrasts were used to compare aboveground production per tiller for 1980 and 1981 . Total nonstructural carbohydrates vs. utilization and western wheatgrass 


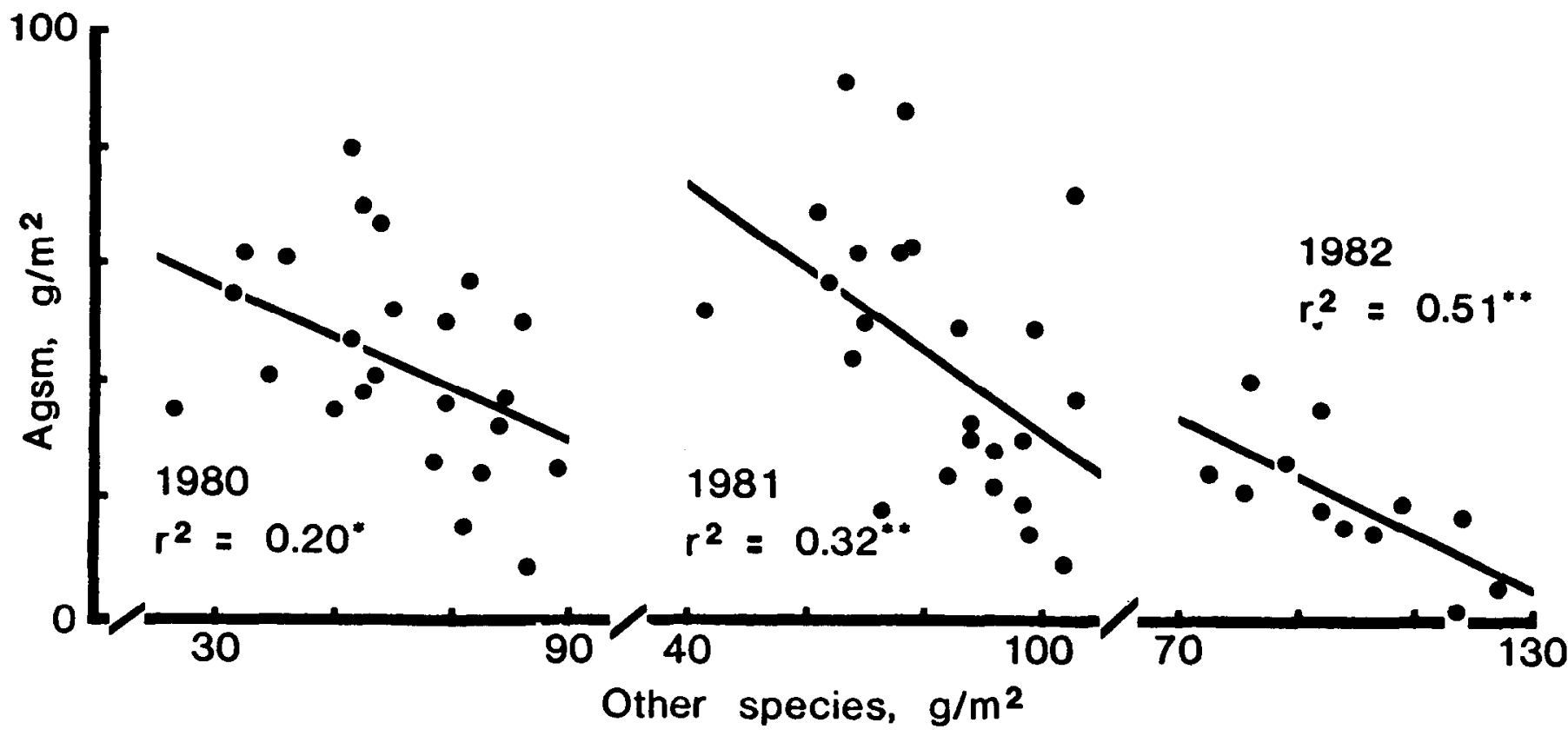

Fig. 2. Correlation between herbage production of western wheatgrass (Agsm) and that of all other species.

production vs. production of other species were analyzed using regression techniques.

\section{Results and Discussion}

\section{Herbage Production}

Under the simulated grazing treatments applied in 1980 , only a narrow range of utilization was achieved (Table 4). This range was

Table 4. Utilization of western wheatgrass under each clipping treatment'.

\begin{tabular}{lccc}
\hline & \multicolumn{2}{c}{$\%$ Utilization } & \\
\cline { 2 - 3 } Treatment & 1980 & 1981 & Mean \\
\hline F111 & 71 & 56 & 64 \\
F112 & 82 & 66 & 74 \\
F2I1 & 83 & 75 & 79 \\
F212 & 86 & 88 & 87 \\
4-clip & 84 & 89 & 86 \\
\hline
\end{tabular}

'See Tables 1 and 2 for explanation of "F" and "I" treatments; "4-clip" was clipped four times during the growing season to a height of $2.5 \mathrm{~cm}$.

widened in 1981 by reducing the frequency of clipping under $F 1$ and the intensity of clipping under 11 (Tables 1 and 2). Under the 2 lighter simulated grazing treatments, the average utilization levels of 64 and $74 \%$ were nearly the same as the 65 and $75 \%$ of western wheatgrass which Hart and Balla (1982) observed under light (.115 $\mathrm{AU} / \mathrm{ha})$ and moderate $(.210 \mathrm{AU} / \mathrm{ha})$ stocking rates, respectively. Utilization under the 4-clip treatment was nearly the same as that under F212, the heaviest simulated grazing treatments.

Total western wheatgrass production adjusted for tiller numbers was greatest under F112, the second heaviest simulated continuous grazing treatment, in 1980 (Table 5). This treatment produced $(\mathrm{P}<.10)$ more herbage than all other treatments except the 4-clip which produced more herbage than the ungrazed or FIII. In 1981 an almost complete reversal in the amount of production was observed with the ungrazed treatment producing a greater amount of forage than the heaviest continuous (F212) or 4-clip treatments. No significant differences were observed in forage production among the ungrazed and 3 lighter simulated continuous grazing treatments (FIII, FI12, F211).

In 1981 , adjusted yields of western wheatgrass on the ungrazed and F1II treatments were 52 and $44 \%$ more, respectively, than in 1980. Western wheatgrass under the 3 heaviest simulated grazing treatments (F112, F2I1, F2I2) produced similar amounts of forage in both years while forage production under the 4-clip treatment was $58 \%$ less in 1981 .

Table 5. Herbage production of western wheatgrass (values adjusted for tiller numbers by covariance analysis).

\begin{tabular}{lccc}
\hline & \multicolumn{2}{c}{ Production, $\mathrm{g} / \mathrm{m}^{2}$} & \\
\cline { 2 - 3 } Treatment ${ }^{1}$ & 1980 & 1981 & $1982^{3}$ \\
\hline Ungrazed & $40 \mathrm{c}^{2}$ & $60 \mathrm{a}$ & $21 \mathrm{a}$ \\
F1I1 & $37 \mathrm{c}$ & $54 \mathrm{ab}$ & $25 \mathrm{a}$ \\
F112 & $53 \mathrm{a}$ & $52 \mathrm{ab}$ & $30 \mathrm{a}$ \\
F2I1 & $41 \mathrm{bc}$ & $47 \mathrm{ab}$ & $18 \mathrm{a}$ \\
F212 & $41 \mathrm{bc}$ & $44 \mathrm{~b}$ & $20 \mathrm{a}$ \\
4-clip & $51 \mathrm{ab}$ & $21 \mathrm{c}$ & $3 \mathrm{~b}$ \\
Standard deviation & 8 & 9 & 7 \\
\hline
\end{tabular}

'See Tables 1 and 2 for explanation of "F" and "I" treatments; "4-clip" was clipped four times during the growing season to a height of $2.5 \mathrm{~cm}$.

${ }^{2}$ Means in the same year followed by the same letter are not different at $P=0.10$.

${ }^{3}$ Two replications only; not adjusted.

When the remaining 2 replications were clipped at the end of the growing season in 1982, after complete rest from defoliation during the year, no significant differences in forage production were observed among the ungrazed or simulated continuous grazing treatments (Table 5). The 4-clip treatment produced significantly less forage than the ungrazed or simulated continuous grazing treatments.

Above-average May-July precipitation in 1981 (Table 6) may have been a contributing factor in increased forage production on the check treatment. In 1980 precipitation was $146 \%$ of average during the winter months (January-April) but $80 \%$ of average during May-July. The reverse was true for 1981 with precipitation $69 \%$ of average January-April, but $177 \%$ of average during May-July.

Cumulative aboveground biomass production per spring tiller of western wheatgrass in 1980 and 1981 is displayed in Figure 1. By late August, the 3 heavier simulated continuous grazing treatments (F1I2, F2I1, F2I2) had almost equal amounts of forage removed and the differences in total herbage production are due to the 
Table 6. Monthly precipitation at High Plains Grasslands Research Station, Cheyenne, WY, 1980-1982.

\begin{tabular}{lrrrc}
\hline \hline & \multicolumn{4}{c}{ Precipitation mm } \\
\cline { 2 - 5 } Month & 1980 & 1981 & 1982 & $\begin{array}{c}1871-1982 \\
\text { Mean }\end{array}$ \\
\hline January & 48 & 6 & 9 & 11 \\
February & 23 & 14 & 6 & 15 \\
March & 45 & 25 & 2 & 26 \\
April & 30 & 24 & 16 & 48 \\
May & 72 & 172 & 96 & 61 \\
June & 2 & 20 & 98 & 43 \\
July & 50 & 80 & 97 & 50 \\
August & 20 & 24 & 44 & 39 \\
September & 28 & 30 & 91 & 30 \\
October & 30 & 29 & 26 & 23 \\
November & 14 & 4 & 16 & 13 \\
December & 2 & 16 & 20 & 12 \\
Total & 361 & 444 & 520 & 372 \\
\hline
\end{tabular}

stubble remaining after the "grazing season" (harvested in September). Cumulative forage production per tiller from the simulated continuous treatments increased almost linearly thru August, while the 4-clip treatment produced little additional herbage per tiller after 30 June 1980 and 21 July 1981.

A significant negative correlation existed between western wheatgrass herbage production and total herbage production of other species (Fig. 2). The higher correlation in 1981 and 1982 may be attributed to decreased competition of western wheatgrass following clipping.

\section{Tiller Density}

No significant changes were observed from May 1980 to September 1981 in tiller numbers under the simulated continuous grazing treatments, but tiller numbers decreased $57 \%$ under 4-clip and increased $28 \%$ on the ungrazed check (Fig. 3).

On the 2 replications remaining in the fall of 1982, after 1 year without defoliation, the check and the 4 simulated grazing treatments averaged 279 tillers $/ \mathrm{m}^{2}$ with no difference among treatments. The 4-clip treatment had fewer tillers, $80 / \mathrm{m}^{2}$, than all other treatments. The continued decline of tiller numbers in the 4-clip treatment indicated the severity of this treatment. Troughton (1957) indicated that reduction in tiller numbers can be expected after defoliation, with greater reduction under more severe defoliation.

Apical meristems of western wheatgrass plants in this study were susceptible to removal by grazing animals as early as June $\mathbf{2 3}$ (Table 7), but increased tiller numbers were observed only in the ungrazed treatment. Tiller numbers remained relatively stable under the continuous treatment and declined under the 4-clip treatment. Removal of the apical meristem in graminoids generally

Table 7. Apical meristem heights, number of tillers sampled, and phenology states of western wheatgrass, 1981.

\begin{tabular}{lccl}
\hline \hline Date & Number & $\begin{array}{c}\text { Meristem } \\
\text { height, cm }\end{array}$ & Phenological stage \\
\hline 26 May & 18 & 0.0 & $1-2$ leaves \\
9 Jun & 18 & 1.4 & 3 leaves, stem elongation \\
23 Jun & 18 & 2.5 & Stem elongation \\
7 Jul & 23 & 5.8 & Stem elongation \\
21 Jul & 22 & 5.8 & Stem elongation \\
4 Aug & 29 & 7.5 & Stem elongation \\
18 Aug & 23 & 7.6 & Stem elongation \\
11 Sep & 21 & 7.2 & Stem elongation \\
\hline
\end{tabular}

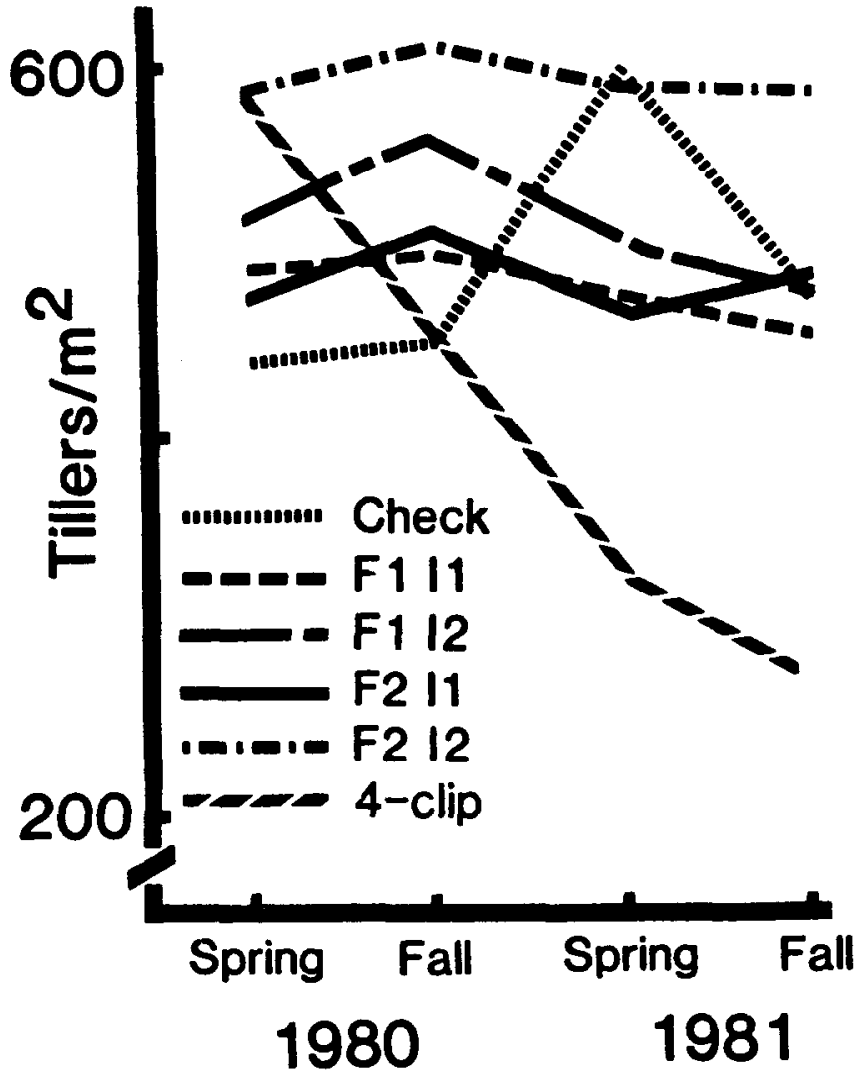

Fig 3. Tiller populations of western wheatgrass under six treatments (see Tables 1 and 2 for explanation of " $F$ " and " $I$ " treatments; "4-clip" was clipped 4 times during the growing season to a height of $2.5 \mathrm{~cm}$ ).

results in increased tillering due to the removal of apical dominance (Hyder 1972). However, an interdependence among the connnected tillers of rhizomatous species like western wheatgrass may maintain the apical dominance of the remaining meristems. The large increase in tiller numbers on the unclipped check in the spring of 1981 may reflect above-average spring precipitation.

Although the percent of the total herbage removed in the 4-clip treatment was almost the same as that removed under the F2I2 treatment in both years, declines in aboveground productivity and tiller numbers were much greater under 4-clip. Other researchers who have uniformly clipped all tillers of western wheatgrass plants have observed large decreases in aboveground production (Lang and Barnes 1962, Everson 1966, Menke 1973, Santos and Trlica 1978, Holscher 1945, Branson 1956). Uniform clipping treatments are not suitable for western wheatgrass and cause much greater decreases in herbage production than similar utilization under continuous grazing.

\section{Belowground Production and TNC Content}

The belowground phytomass production differences among treatments generally correspond with the aboveground production differences (Table 8). Among the treatments, both aboveground and belowground production were generally inversely proportional to the frequency and intensity of defoliation. The 4-clip treatment, however, produced $48 \%$ of the aboveground production and $60 \%$ of the total belowground production of the heaviest simulated continuous grazing treatment (F2I2) in 1981, even through the precipitation rates were nearly equal. Everson (1966), Santos and Trlica (1978), and Bokhari and Singh (1974) all reported declines in underground productivity of western wheatgrass due to clipping.

Mean total nonstructural carbohydratc (TNC) concentration over all treaments was $5.4,7.0$, and $10.8 \%$ in roots, crowns, and rhizomes, respectively. Each of these values was significantly dif- 
Table 8. Root, crown, and rhizome biomass of western wheatgrass (values adjusted for tiller numbers by covariance analysis).

\begin{tabular}{|c|c|c|c|c|}
\hline Treatment ${ }^{1}$ & Ronts & Crowns & Rhizomes & Total \\
\hline & \multicolumn{4}{|c|}{$\mathrm{g} / \mathrm{m}^{2}$} \\
\hline Ungrazed & $114 \mathrm{a}^{2}$ & $47 a$ & $24 \mathrm{a}$ & $185 \mathrm{a}$ \\
\hline F1II & $94 \mathrm{a}$ & $40 \mathrm{a}$ & 23 a & $157 \mathrm{ab}$ \\
\hline F112 & $77 \mathrm{ab}$ & $43 a$ & $19 a$ & $139 a b c$ \\
\hline F2II & $96 \mathrm{a}$ & $42 a$ & $16 \mathrm{a}$ & $154 \mathrm{ab}$ \\
\hline F212 & $58 \mathrm{ab}$ & $30 \mathrm{a}$ & $18 \mathrm{a}$ & $106 \mathrm{bc}$ \\
\hline 4-clip & $26 \mathrm{~b}$ & $23 \mathrm{a}$ & $13 \mathrm{a}$ & $63 \mathrm{c}$ \\
\hline \multicolumn{5}{|l|}{ Standard } \\
\hline deviation & 23 & 8 & 5 & 33 \\
\hline
\end{tabular}

'See Tables 1 and 2 for explanation of "F" and "I" treatments; "4-clip" was clipped four times during the growing season to a height of $2.5 \mathrm{~cm}$.

${ }^{2}$ Values in the same column followed by the same letter are not different at $P=0.10$.

ferent from the other two $(P<.05)$. Everson (1966) noted the importance of rhizomes of western wheatgrass as storage organs upon finding $471 \%$ more soluble sugars and $177 \%$ more starch per gram in the rhizomes over the tops or roots among the unclipped plants.

TNC response to increasing utilization followed the same discontinuous curve as the response of animal gains (Hart 1978) and conception rates (Hart et al, 1982) to increasing grazing pressures. TNC remained constant until utilization reached a critical point; then TNC decreased in a straight line as utilization increased beyond the critical point. Herbage removal from western wheatgrass plants affected rhizome TNC values before it affected root or crown TNC values (Fig. 4, Table 9). Rhizome TNC began to decline at approximately $39 \%$ utilization, representing the intercept of the regression line for the clipped treatments with the TNC level of the control. Root and crown TNC values were more tolerant of herbage removal and did not decline until utilization

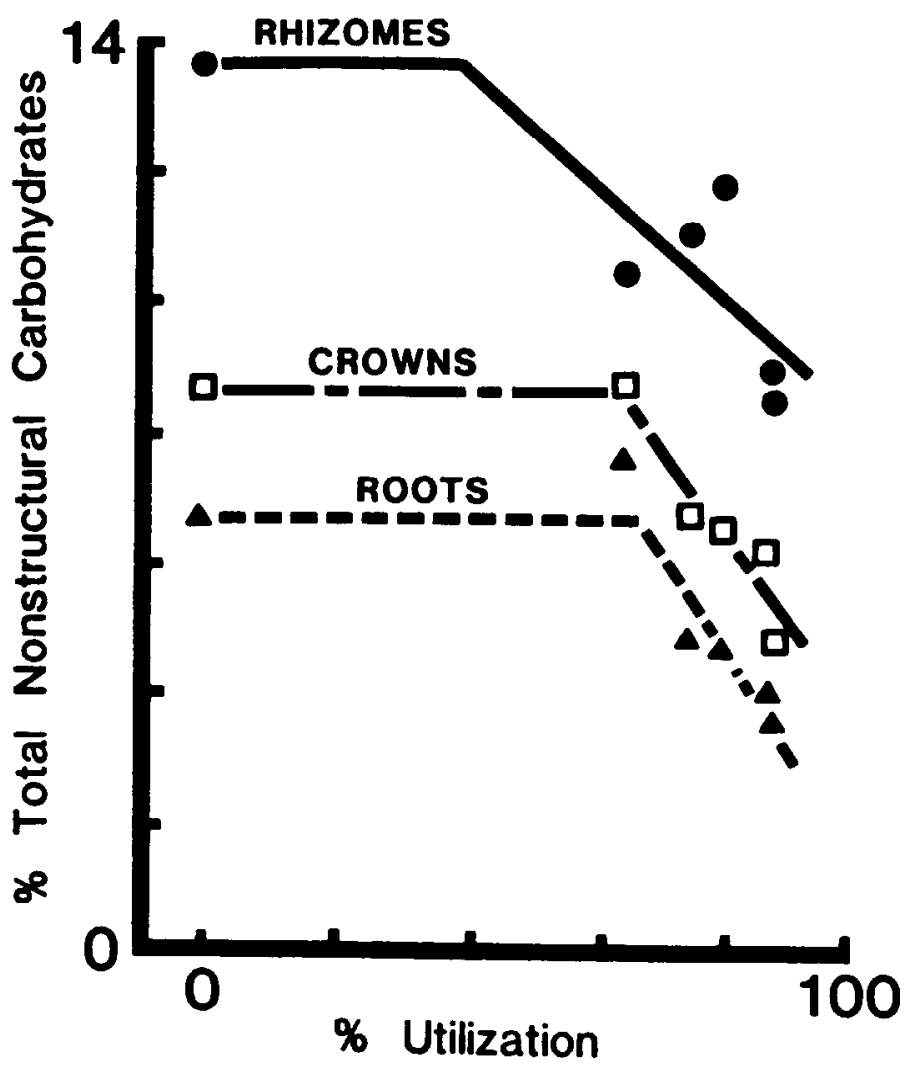

Fig. 4. Level of utilization and total nonstructural carbohydrate concentration in rhizomes, crowns, and roots of western wheatgrass.
Table 9. Regression of total nonstructural carbohydrates (TNC) concentration in rhizomes, crowns, and roots of western wheatgrass on percent utilization (U).

\begin{tabular}{lcccc}
\hline \hline & & \multicolumn{3}{c}{$\%$ TNC } \\
\cline { 3 - 5 } & $\begin{array}{c}\text { Critical } \\
\text { point } \\
\text { Organ }\end{array}$ & $\begin{array}{c}\text { Below } \\
\text { critical }\end{array}$ & & \\
\hline Rhizomes & 39 & 13.7 & TNC $=17.2-0.09 \mathrm{U}$ & $0.72^{*}$ \\
Crowns & 63 & 8.7 & TNC $=17.5-0.14 \mathrm{U}$ & $0.92^{* *}$ \\
Roots & 68 & 6.7 & TNC $=16.9-0.15 \mathrm{U}$ & $0.87^{* *}$ \\
\hline
\end{tabular}

reached 68 and $63 \%$, respectively. This suggests that rhizomes play a greater role in providing stored reserves needed for regrowth than either crowns or roots under light or moderate levels of herbage removal, but as removal rates became heavier, stored reserves may be mobilized from roots (Bokhari 1977) and crowns also.

The decline in both belowground phytomass and TNC concentrations under severe clipping produced a large decline in total TNC available for regrowth. Total TNC in $\mathrm{g} / \mathrm{m}^{2}$ for the check was 15.0; F111, 13.1; F1I2, 8.9; F211, 9.3; F212, 5.3; and 4-clip, 3.6.

\section{Conclusions}

During 2 years, simulated continuous grazing of western wheatgrass resulted in no major decrease of aboveground or belowground production below the unclipped check until utilization exceeded $80 \%$. Both above- and belowground production declined sharply under 4 uniform clips per year, although herbage removal was the same as under the most severe simulated grazing treatment. As utilization increased, rhizomes appeared to be the first storage organ in which TNC concentration was affected; this occurred at approximately $40 \%$ utilization. Klipple and Costello (1960) and Reed and Peterson (1961) reported that forage production of western wheatgrass began to decline when grazing use reached 20 to $40 \%$.

The use of clipping to estimate proper stocking and utilization of plants appears to have become less frequent in recent years, possibly due to the difficulty of correlating the removal rates by clipping to those obtained under actual grazing by herbivores. Clipping which more accurately simulates removal rates by herbivores, as in this study, can provide a more accurate assessment of the impact of those herbivores.

\section{Literature Cited}

Bokhari, U.G. 1977. Regrowth of western wheatgrass utilizing 14C-labeled assimilates stored in belowground parts. Plant and Soil 48:115-127.

Bokhari, U.G., and J.S. Singh. 1974. Effects of temperature and clipping on growth, carbohydrate reserves, and root exudation of western wheatgrass in hydroponic culture. Crop Sci. 14:790-794.

Branson, F.A. 1956. Quantitative effects of clipping treatments on five range grasses. J. Range Manage. 9:86-88.

Everson, A.C. 1966. Effects of frequent clipping at different stubble heights on western wheatgrass (Agropyron smithii Rydb.). Agron. J. 58:33-35.

Harris, W. 1976. Defoliation as a determinant of the growth, persistence and composition of pasture. p. 67-85. In: J.R. Wilson (ed.) Plant relations in pastures. CSIRO, Melbourne.

Hart, R.H. 1978. Stocking rate theory and its application to grazing on rangelands. Proc. First Internat. Range. Cong. p. 550-553.

Hart, R.H., and E.F. Balla. 1982. Forage production and removal from western and crested wheatgrasses under grazing. J. Range Manage. 35:362-366.

Hart, R.H., J.W. Waggoner Jr., T.G. Dunn, and L.D. Adams. 1982. Gains and conception rates of cattle on complementary spring pastures. Proc. 3rd Annu. Wagonhound Field Day, p. 27-28. Univ. Wyoming Coll. Agr. Div. Animal Sci. \& Range Manage.

Heady, H.F. 1961. Continuous vs. specialized grazing systems: a review and application to the California annual type. J. Range Manage. 14:182-193. 
Holscher, C.E. 1945. The effects of clipping bluestem wheatgrass and blue grama at different heights and frequencies. Ecology. 26:148-156.

Hyder, D.N. 1972. Defoliation in relation to vegetative growth, p. 304-317. In: V.B. Youngner and C.M. McKell (eds.) Biology and utilization of grasses. Academic Press Inc., N.Y.

Jameson, D.A. 1963. Responses of individual plants to harvesting. Bot. Rev. 29:332-394.

Klipple, C.E., and D.F. Costello. 1960. Vegetation and cattle responses to different intensities of grazing on short grass range on the Central Great Plains. USDA. Tech. Bull. 1216.

Lang, R., and O.K. Barnes. 1952. Range forage production in relation to time and frequency of harvesting. Wyoming Agr. Exp. Sta. Bull. 253.

Menke, J.W. 1973. Effects of defoliation on carbohydrate reserves, vigor and herbage yield for several important Colorado range species. Ph.D. Diss. Colorado State Univ., Fort Collins.
Reed, M.J., and R.A. Peterson. 1961. Vegetation, soil and cattle responses to grazing on Northern Great Plains range. USDA. Forest Serv. Tech. Bull. 1252.

Santos, G.L., and M.J. Trlica. 1978. Clipping effects on production and carbohydrates of blue grama and western wheatgrass. Proc. Ist Internat. Range Cong. p. 384-386.

Smith, D. 1981. Removing and analyzing total nonstructural carbohydrates from plant tissue. Res. Div. College Agr. and Life Sci., R. 2107, Univ. Wisconsin.

Stevenson, A., R.E. Baumgartner, and G.E. Schuman. 1984. High Plains Grasslands Research Station, Cheyenne, Wyoming, detailed soil survey. Univ. Wyoming Agr. Exp. Sta., Laramie.

Troughton, A. 1957. The underground organs of herbage grasses. Comm. Bur. Pastures Field Crops. Bull. 44. 